\title{
Cultured Rat Embryo Accumulation of DNA, RNA, and Protein following Maternal Administration of Sodium Arsenate
}

\author{
D. L. FISHER \\ Department of Anatomy, The University of Michigan, Ann Arbor, Michigan 48109
}

Received September 11, 1980

\begin{abstract}
Whole embryo culture techniques were used to test the effects of sodium arsenate on the rates of DNA, RNA, and protein accumulation. Rat embryos were isolated on the 10th gestational day (sperm day = Day 0 ) either 4 or $24 \mathrm{hr}$ after maternal injection. The cultivation period was for 24 or $42 \mathrm{hr}$. DNA, RNA, and protein values were not significantly different for in utero treatment $4 \mathrm{hr}$ prior to dissection. For embryos treated in utero $24 \mathrm{hr}$ prior to dissection, DNA, RNA, and protein levels were significantly lower at the beginning of cultivation and after $24 \mathrm{hr}$ in culture. By $42 \mathrm{hr}$, DNA and RNA values were still significantly reduced. A number of morphologic differences were also noted following cultivation for embryos treated in utero $24 \mathrm{hr}$ prior to dissection. These include a significant number of embryos failing to (1) rotate to a ventroflexed position, (2) have a closed anterior neuropore, (3) establish a visceral yolk sac circulation, and (4) fuse the allantoic sac in placental formation. It is concluded that sodium arsenate takes longer than $4 \mathrm{hr}$ to affect the embryo and that a 24-hr in utero exposure is adequate to initiate teratogenic responses. The abnormal persistence of a definitive allantoic sac after culture may be indicative of abnormalities in urogenital system formation. The effects of sodium arsenate seem to be related to proliferative embryonic cell requirements with some insult recovery of the embryo possible.
\end{abstract}

\section{INTRODUCTION}

The effects on embryonic development of a number of metal and metal-like elements found in the environment have been of interest for a long time because of their teratogenic potential (see review of literature by Ferm 1972, 1974). The metalloid arsenic is no exception, as several compounds of this element are teratogenic. Sodium arsenate has been shown to be teratogenic in the hamster (Ferm and Carpenter, 1968; Ferm et al., 1971) and rat (Beaudoin, 1974; Burk and Beaudoin, 1977). Both sodium arsenate, the pentavalent compound, and sodium arsenite, the trivalent compound, are teratogenic in the mouse (Hood and Bishop, 1972; Hood, 1972).

It has been shown that arsenic does reach the fetus but at a very low rate (Burk, 1976). It is effective in in vitro uncoupling of oxidative phosphorylation (Crane and Lipman, 1953) and may be effective in inhibiting the activity of the sulfhydryl enzymes (Hood and Pike, 1972).

The present study was conducted to determine some of the effects arsenic may have on cellular proliferation and metabolism of the embryo, as well as to give some indication of the rate at which it may exert its teratogenic effects. Several alternative methods could be employed to answer questions regarding the rate of response by the maternal-embryonic axis to a teratogenic agent. An injection at a 
specific time with removal at various intervals for assay would tell us when initial embryonic response to a teratogenic agent begins to be apparent. It would not, however, tell us when initial embryonic response occurred. An injection at a specific time with embryonic removal to an in vitro environment at various intervals for continued cultivation and subsequent assay would be ideal. However, unanswered technical difficulties make comparisons between groups cultivated at various gestational ages impossible at present. If the mothers are injected at various times with removal of embryos to in vitro cultivation at a constant technically feasible period, it is obvious that the teratogenic response may be different both morphologically and perhaps biochemically. If the latter method is chosen, however, two criteria must be observed. First, the agent must be teratogenically effective at each time chosen for administration, and second, morphologic and biochemical differences must be noted between experimentals and concomitant controls and not between experimental groups.

Since arsenic has been determined to be teratogenic at both Day 9 and Day 10 of development (Beaudoin, 1974), the latter method was utilized. The embryos were recovered from the uterus on Day 10 of gestation 4 and $24 \mathrm{hr}$ after maternal administration of sodium arsenate and cultured in vitro with concomitant controls for from 24 to $42 \mathrm{hr}$.

\section{MATERIALS AND METHODS}

\section{Animal Procedures and Culture}

Wistar-derived rats maintained in our laboratories were fed Teklad rat diet (Teklad Mill, Winfield, Iowa) and water ad libitum with weekly supplemental feeding of lettuce. Temperatures were $68-70^{\circ} \mathrm{F}$ and a $14-\mathrm{hr}$ light cycle was maintained throughout. In the evenings, a single male was placed with three to six virgin females $(\sim 150 \mathrm{~g})$ and vaginal sperm was checked the following morning. The discovery of sperm was designated Day 0 of pregnancy.

Pregnant females were injected ip with basic sodium arsenate (J. T. Baker, Co., Phillipsberg, N.J.) at $45 \mathrm{mg} / \mathrm{kg}$ maternal body weight either 4 or $24 \mathrm{hr}$ before dissection on late mornings on Day 10. Control animals were either sham injected or not injected with the water vehicle. As no significant differences were noted between the results of the two methods for control embryos, data were pooled.

Dissection was according to the method of New and Coppola (1977). At this time, the embryos normally have 5-9 somites, are dorsiflexed, have neuropores open, have an absence of limb buds, have an allantoic sac separated from the amniotic sac, and do not have a visceral yolk sac circulation evident. Cultivation conditions followed the method of Kochhar (1975) using 50\% Waymouth's medium (GIBCO, Grand Island, N.Y.) and 50\% fetal calf serum (GIBCO). The Waymouth's medium was supplemented with $5000 \mathrm{U} /$ liter penicillin and 5000 $\mu \mathrm{g} /$ liter streptomycin. Embryos with the visceral yolk sac intact were individually placed in a $10-\mathrm{ml}$ screw-top plastic tube containing $1.5 \mathrm{ml}$ of medium maintained at $37^{\circ} \mathrm{C}$ and rotated on a mechanical rotator at $30-40 \mathrm{rpm}$. The gassing sequences used were those suggested by New and Coppola (1977), beginning with $10 \% \mathrm{O}_{2}$, $5 \% \mathrm{CO}_{2}$, and $85 \% \mathrm{~N}_{2}$. The $\mathrm{O}_{2}$ was increased every 12 hr to 20,50 , and finally $80 \%$. Nitrogen was decreased concomitantly. The $5 \% \mathrm{CO}_{2}$ was held constant for stabili- 
zation of $\mathrm{pH}$. The embryos were either terminated after $24 \mathrm{hr}$ or transferred to fresh medium and cultivation continued for $42 \mathrm{hr}$. Six separate experimental trials for each 4- and 24-hr exposure were made using a total of 28 dams, 186 cultivated embryos, and 273 total embryos.

\section{Analytic Methods}

1. Gross anatomical parameters. At the termination of cultivation, a number of developmental parameters were analyzed. Differences in growth were selectively noted in controls and experimentals using photographic measurements in centimeters for head, heart, body, and tail. Heart rate was timed by stopwatch for 15 sec at $37^{\circ} \mathrm{C}$. Somite numbers were counted. Over the time period chosen for cultivation, a number of morphologic changes in the embryo occur in vivo. These include: closure of the anterior neuropore, rotation to a ventroflexed position, indication of anterior limb bud swellings, establishment of visceral yolk sac circulation, and fusion of the amniotic and allantoic sacs. Subjective comparisons of treated and nontreated embryos were made for these. The presence or absence of an edematous condition in the pericardial sac or ventricles of the brain was also noted for cultivated embryos.

2. Protein analysis. Analysis followed the method of Lowry et al. (1951). At 0 and $24 \mathrm{hr}$ the homogenate of one embryo was used for analysis. At $42 \mathrm{hr}$ the homogenate could be diluted by one-half.

3. DNA and RNA analysis. Analysis was by the ethidium bromide fluorometric technique of Prasad et al. (1972) as modified by Dr. E. Ritter (personal communication, 1978) to include the expected DNA and RNA values of 10- to 12-day rat embryos for the determined standard curves. The spectrophotofluorometer excitation wave length was $365 \mathrm{~nm}$ and emission wave length was $590 \mathrm{~nm}$. Analysis was made al 0,24 , and/or $42 \mathrm{hr}$ of culture for each experiment.

4. Statistical analysis. A multiple linear regression analysis was used with $P$ values less than 0.05 indicating a level of significance. Student's $t$ test was used for comparisons between the treated and nontreated embryos. An analysis of variance and Dunnett's $d$ statistic were also compared. The correlation coefficients of linearized standard curves were all greater than $r=0.98$.

\section{RESULTS}

\section{Gross Anatomical Differences}

There were a number of morphologic variations noted for embryos treated in utero $24 \mathrm{hr}$ before dissection. The significant differences noted after $24 \mathrm{hr}$ in culture between 38 control and 71 experimental embryos were a decrease in the number turning to a ventroflexed position, the retention of an open anterior ncuroporc, and irregular facial development (statistics presented elsewhere; Beaudoin and Fisher, 1981). In addition to this, there was a significant decrease in the number of embryos establishing a visceral yolk sac circulation. Control embryos with a visceral yolk sac circulation were $79.0 \pm 6.7 \%$ as compared to $58.3 \pm$ $5.9 \%$ of the experimentals. Probably the most striking variation noted was a failure of fusion of the allantoic sac in placental development. This occurred in 
D. L. FISHER

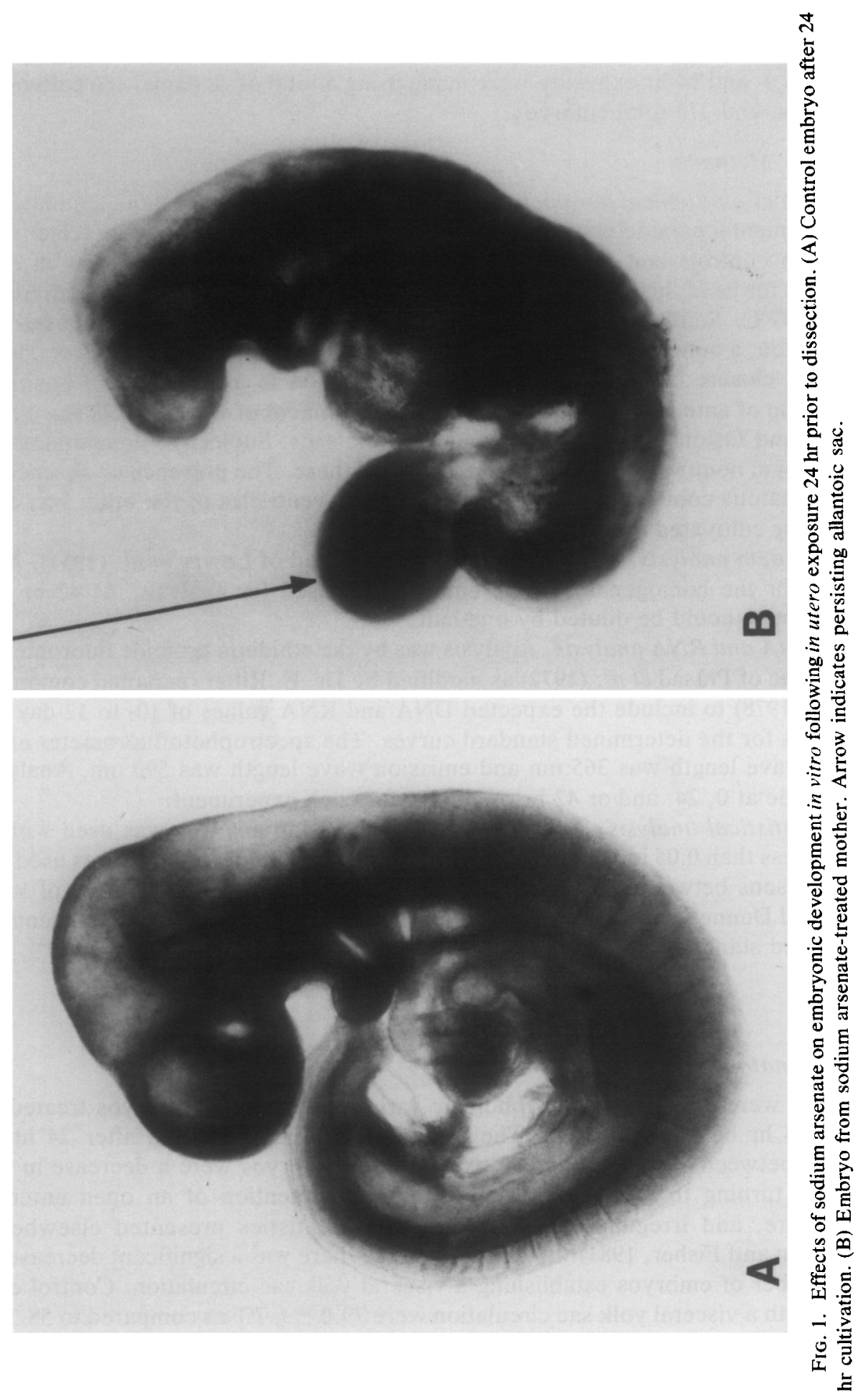




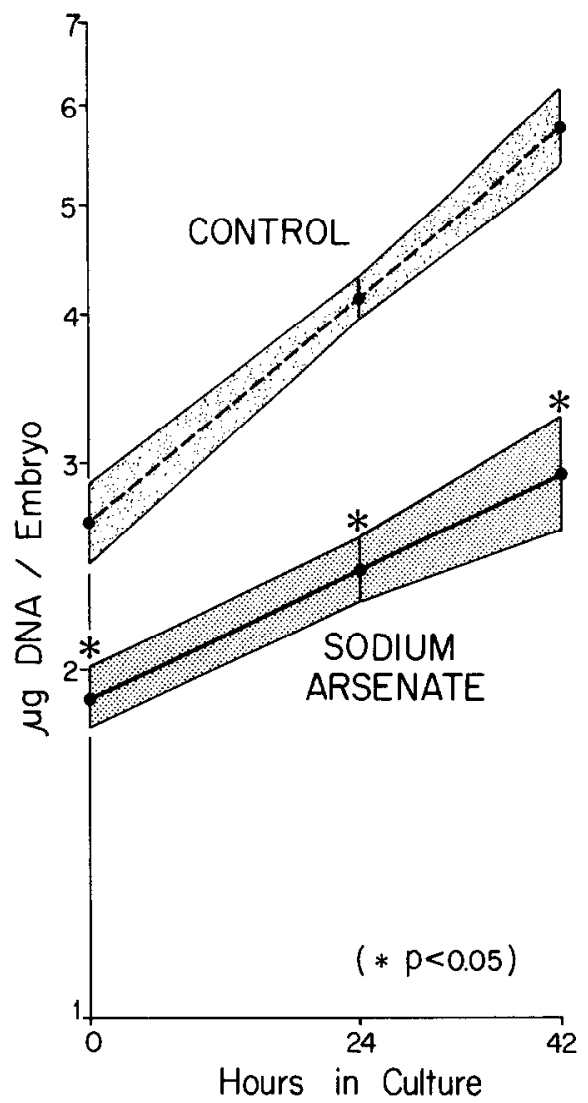

FIG. 2. Effects of sodium arsenate on DNA accumulation in the embryo over the cultivation period following in utero exposure $24 \mathrm{hr}$ prior to dissection. Changes in value using slope and intercept were determined for each trial of control and experimental embryos over the cultivation period. Data were pooled with a mean and standard error at 0,24 , and $42 \mathrm{hr}$ as indicated. Each point represents separate measurements on approximately 20 embryos.

less than $4 \%$ of the controls and in $51 \pm 6.6 \%$ of the experimentals (Fig. 1). No gross anatomical differences between controls and experimentals were noted for embryos treated in utero just $4 \mathrm{hr}$ prior to dissection. No significant differences were noted for either injection time concerning the number of somites added or the appearance of anterior limb buds.

\section{Biochemical Differences following Cultivation of Embryos Exposed in Utero hefore Dissection}

Approximately 40 embryos were used for each biochemical assay period. No significant differences were noted for DNA, RNA, or protein accumulation in those embryos treated in utero $4 \mathrm{hr}$ prior to dissection. For embryos treated $24 \mathrm{hr}$ prior to dissection, DNA, RNA, and protein accumulation values were significantly reduced at the beginning of cultivation. After $24 \mathrm{hr}$ in culture, DNA, RNA, and protein accumulation values remained significantly lower and DNA and RNA accumulation values were significantly reduced after $42 \mathrm{hr}$ in culture. Protein 


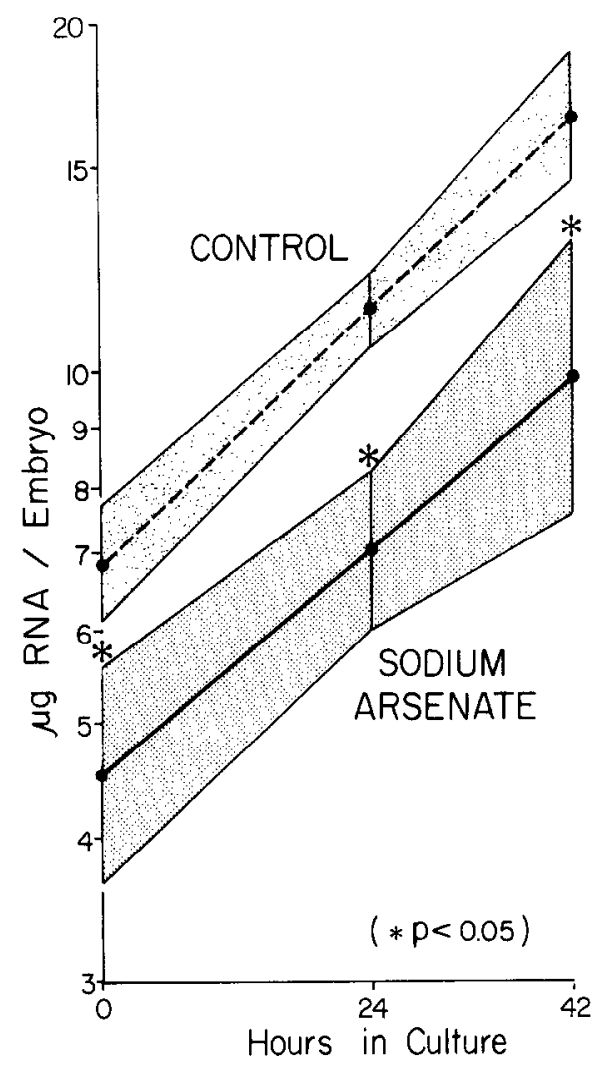

FIG. 3. Effects of sodium arsenate on RNA accumulation in the embryo over the cultivation period following in utero exposure $24 \mathrm{hr}$ prior to dissection. Changes in value using slope and intercept were determined for each trial of control and experimental embryos over the cultivation period. Data were pooled with a mean and standard error at 0,24 , and $42 \mathrm{hr}$ as indicated. Each point represents separate measurements on approximately 20 embryos.

accumulation values were lower than those of controls after $42 \mathrm{hr}$, but were no longer significant (Figs. 2, 3, and 4). If the percentage increase of control over experimental embryos is compared for accumulation of DNA, RNA, and protein, a significant drop in DNA, RNA, and protein accumulation is noted for embryos exposed in utero for $24 \mathrm{hr}$ (Table 1). An exposure for $4 \mathrm{hr}$ was not significantly different in any aspect.

\section{DISCUSSION}

From studies conducted during embryonic gestation, a moderate amount of information has been gained concerning the placental transfer of arsenic. Much of this information concerns the past use of organic arsenicals as a therapeutic prevention of congenital syphilis in the newborn. The arsenicals are stored within the embryonic portion of the human placenta and are slowly released into the fetal circulation (Eastman, 1931). In experiments with rabbit and cat pregnancies, Underhill and Amatruda (1923) found that large amounts of arsenic were stored in 


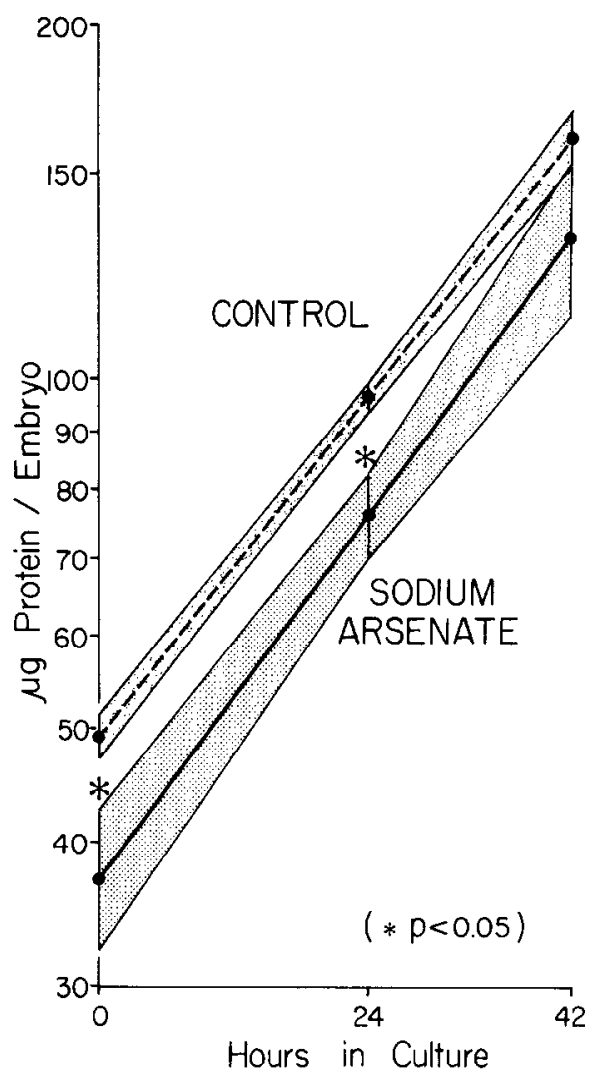

Fig. 4. Effect of sodium arsenate on protein accumulation in the embryo over the cultivation period following in utero exposure $24 \mathrm{hr}$ prior to dissection. Changes in value using slope and intercept were determined for each trial of control and experimental embryos over the cultivation period. Data were pooled with a mean and standard error of 0,24 , and $42 \mathrm{hr}$ as indicated. Each point represents separate measurements on approximately 20 embryos.

the placenta after the administration of the organic arsenical arsphenamine and that only very small amounts could be found in embryonic tissue. They concluded that there was a very slow transfer of this compound from mother to embryo.

This appears to be the case with rat embryos. A 4-hr exposure to arsenic, with subsequent removal of the parietal yolk sac portion of the placentas of the embryos followed by an in vitro cultivation period yielded no significant differences between experimental and control embryos by either the morphologic or the biochemical parameters examined. The establishment of a visceral yolk sac circulation in the treated embryos was also unaffected. A 24-hr in utero exposure appears sufficient, however, to affect both the morphologic and biochemical differentiation of the embryo.

Although both DNA and RNA values were significantly reduced throughout cultivation for embryos treated in utero $24 \mathrm{hr}$ prior to dissection, the embryonic ability to accumulate protein seemed to recover from insult (Table 1 and Fig. 4). It is also possible that there is a degradation of both DNA and RNA with a retarded 
TABLE 1

Percentage Increase of Control over Experimental Rat Embryos Receiving Maternal Injection of Sodium Arsenate on Day 9 of Development and Dissected on Day 10

\begin{tabular}{ccccc}
\hline $\begin{array}{c}\text { Cultivation } \\
\text { time (hr) }\end{array}$ & $\begin{array}{c}\text { Number } \\
\text { assayed }\end{array}$ & $\begin{array}{c}\text { DNA } \\
\text { accumulation } \\
(\% \Delta)\end{array}$ & $\begin{array}{c}\text { RNA } \\
\text { accumulation } \\
(\% \Delta)\end{array}$ & $\begin{array}{c}\text { Protein } \\
\text { accumulation } \\
(\% \Delta)\end{array}$ \\
\hline 0 & 41 & $42.1 \pm 3.1^{*}$ & $53.3 \pm 17.1^{*}$ & $33.2 \pm 14^{*}$ \\
24 & 43 & $70.8 \pm 5.9^{*}$ & $60.6 \pm 13.9^{*}$ & $26.4+7^{*}$ \\
42 & 38 & $100 \pm 7.0^{*}$ & $66.7 \pm 27.3^{*}$ & $21.7 \pm 12.7$ \\
\hline
\end{tabular}

$* P<0.05$.

reformation of new DNA and RNA following insult. The method used, however, allows no definitive conclusions to be made and needs further investigation.

Detailed dissection of the rat (Burk and Beaudoin, 1977) and hamster embryos (Ferm, 1972) revealed that maternal treatment with sodium arsenate caused severe urogenital abnormalities, including renal hypoplasia and agenesis as well as defects in morphology of the uterus and ductus deferens. Burk and Beaudoin (1977) indicated that the underlying renal problems resulted from a retardation in growth of the metanephric and genital ducts. These ducts have an intimate relationship with the urogenital sinus and the allantoic sac in the embryo. The failure of fusion of the allantoic sac in placental formation for embryos from arsenic-treated mothers, as observed during our cultivation, may be indicative of the effects arsenic has on development of the urogenital system.

A general energy reduction resulting in decreased cell production, as we observed in our experimentation for DNA, RNA, and protein accumulation in the embryo, could be postulated to explain the defects observed. The characteristic site specificity of arsenate to the urogenital system seems to suggest, however, the involvement of more specific mechanisms and demands a better understanding of normal urogenital developmental requirements.

\section{ACKNOWLEDGMENTS}

I wish to thank Dr. A. R. Beaudoin for assistance and advisement and Francine Hale for skilled technical assistance. This work was supported by an Environmental Protection Agency grant issued to Dr. A. R. Beaudoin.

\section{REFERENCES}

Beaudoin, A. R. (1974). Teratogenicity of sodium arsenate in rats. Teratology 10, 153-158.

Beaudoin, A. R., and Fisher, D. L. (1981). An in vivo/in vitro evaluation of teratogenic action. Teratology 23, 57-61.

Burk, D. T. (1976). "Inorganic Arsenic: Placenta Transfer and Effect on Embryogenesis of the Urogenital System of the Rat," p. 82. Dissertation submitted in partial fulfillment of the requirements for the degree of Doctor of Philosophy (Anatomy), the University of Michigan, Ann Arbor.

Burk, D., and Beaudoin, A. R. (1977). Arsenate-induced renal agenesis in rats. Teratology 16, $247-259$.

Crane, R. K., and Lipman, F. (1953). The effect of arsenate on aerobic phosphorylation. J. Biol. Chem. 201, 235-243.

Eastman, N. J. (1931). The arsenic content of the human placenta following arsphenamine therapy. Amer. J. Obstet. Gynecol. 21, 60-64. 
Ferm, V. H. (1972). The teratogenic effects of metals on mammalian embryos. Advan. Teratol. 5, $51-75$.

Ferm, V. H. (1974). Effect of metal pollutants upon embryonic development. Rev. Environ. Health, 1, 238-259.

Ferm, V. H., and Carpenter, S. J. (1968). Malformations induced by sodium arsenate. J. Reprod. Fertil. 17, 199-201.

Ferm, V. H., Saxon, A., and Smith, B. W. (1971). The teratogenic profile of sodium arsenate in the golden hamster. Arch. Environ. Health 22, 557-560.

Hood, R. D. (1972). Effects of sodium arsenite on fetal development. Bull. Environ. Contam. Toxicol. 7, 216-222.

Hood, R. D., and Bishop, S. L. (1972). Teratogenic effects of sodium arsenate in mice. Arch. Environ. Health 24, 62-65.

Hood, R. D., and Pike, C. T. (1972). BAL alleviation of arsenate-induced teratogenesis in mice. Teratology 6, 235-237.

Kochhar, D. M. (1975). The use of in vitro procedures in teratology. Teratology 11, 273-288.

Lowry, O. H., Rosebrough N. J., Farr, A. L., and Randall, R. J. (1951). Protein measurement with the Folin phenol reagent. $j$. Biol. Chem. 193, 265-275.

New, D. A. T., and Coppola, P. T. (1977). Development of a placental blood circulation in rat embryos in vitro. J. Embryol. Exp. Morphol. 37, 227-235.

Prasad, A. S., DuMouchelle, E., Koniuch, D., and Oberleas, D. (1972). A simple fluorometric method for the determination of RNA and DNA in tissues. J. Lab. Clin. Med. 80, 598-602.

Ritter, E. (1978). RNA and DNA determination on 10 and 11 day rat embryos. Personal communcation.

Underhill, R. P., and Amatruda, F. G. (1923). The transmission of arsenic from mother to fetus, JAMA 81, 2001-2012. 